\title{
A Comparative Study of the "One Belt and One Road" Initiative and the Marshall Plan
}

\author{
Lezhou LV \\ Vanke Meisha Academy, D1203, Hengyubincheng phase 1, Zhongxin Road, Nanshan District. \\ Lvlz2019@outlook.com
}

\begin{abstract}
The "One Belt and One Road" initiative is fundamentally different from the Marshall plan. The former takes common development as its fundamental attribute, equality and mutual benefit as its principle and pragmatic cooperation as its orientation. The latter is essentially a political and security strategy. The United States initiated the cold war process with the Soviet Union through conditional assistance. Moreover, the implementation of the "One Belt and One Road" initiative will face more challenges than the Marshall plan. It not only needs to respond to the diversified interest demand of countries along the belt and road, but also faces a more complex political and security environment. There's also a lot of outside interference. As for the analogy between the "One Belt and One Road" initiative and the Marshall plan, it needs to be treated rationally and differently, and the two should not be directly opposed. Because from the logic of economic development, there is indeed a commonality between the two. The Marshall plan can also provide both positive and negative experiences and lessons for the implementation of the "One Belt and One Road" initiative.
\end{abstract}

Keywords: "One Belt and One Road" initiative, Marshall Plan, Chinese diplomacy.

\section{Introduction}

With the continuous clarity of the "One Belt and One Road" initiative and the introduction of corresponding measures, there is an increasing number of domestic and international comparisons between "One Belt and One Road" initiative and the US Marshall Plan for the post-war revival of Europe. From the perspective of economic perspective, the domestic media believe that the implementation of the "One Belt and One Road" initiative will bring about the role of Marshall Plan in the process of European economic recovery and regional integration. Western scholars and media mostly start from the political and security perspectives, believing that the "One Belt and One Road" initiative is a political and security strategy for China to operate its sphere of influence and fight for regional dominance in the context of the transfer of international power centre. In fact, although there are some commonalities in these two, there are essential differences in form, content and fundamental starting point.

\section{The Origin of the Concept of "China's Marshall Plan"}

The concept of "China's Marshall Plan" was proposed because domestic and foreign scholars have no connection with the "One Belt And One Road" initiative in solving the financial crisis of international community and China.

(1) Lin yifu's "new Marshall Plan"

Lin yifu, a Chinese economist, has proposed a "new Marshall plan" to tackle the financial crisis, linking the "Marshall plan" to China for the first time. Faced with the challenges of the financial crisis in 2009, Lin yifu said a new "Marshall plan" was needed to boost global investment in infrastructure, to break the bottleneck of economic growth in developing countries and provide space for structural reforms in high-income countries. That is, increasing the export demand of developed countries through investment in global infrastructure. This investment is a win-win situation that allows developed countries to carry out structural reforms and emerge from the financial crisis. Developing countries can get faster development opportunities by eliminating their own infrastructure bottlenecks.

The plan is actually a global cooperation in which countries coordinate and adopt proactive fiscal policies, invest in infrastructure bottlenecks and environmental bottlenecks, and achieve the effect of increasing demand. The plan will be implemented by a number of international development 
institutions, including the World Bank, such as the European development bank, the Asian development bank, the Latin American development bank and the African development bank. The main function of the plan is to rely on the above-mentioned international development agencies and to cooperate with developing countries. In fact, China is only one of the participants in international cooperation in Lin if's "new Marshall Plan", which is not necessarily related to the current "One Belt and One Road" initiative.

(2) Xu shade's "China's Marshall plan"

It was $\mathrm{Xu}$ shade, a famous economist, who first proposed implementing the "China's Marshall Plan". In 2009, when China's exports slowed under the impact of the financial crisis, Xu shanda, a member of the national committee of CPPCC, proposed using the "China's Marshall plan" to create domestic demand, namely, led by the Chinese government, the initiative of large-scale directional investment overseas.

$\mathrm{Xu}$ shade advised the country to design a foreign aid program, using a certain amount of foreign currency reserves and $\mathrm{RMB}$, to provide aid to developing countries. Aid projects are focused on infrastructure, such as electricity, water, roads, railways, ports, minerals and energy. Recipient countries can choose different projects according to their own needs and repay corresponding debts by means of national credit and project fees.

Specifically, the plan involves three measures. A Chinese international aid and cooperation fund will be set up to make loans in the name of the government. Government loans will lead the domestic enterprises which has excess capacity to "go global". It is coordinated with the internationalization of RMB, pushing RMB to be an international currency, a payment currency and a reserve currency. On the one hand, the plan can transform domestic excess capacity into national debt, create and cultivate new external demand, and buy time and financial resources for increasing domestic consumption rate. At the same time, it can narrow the global gap between the rich and the poor and create conditions for the fundamental reform of the current international economic order, especially the financial order. The biggest similarity to the Marshall plan is that it is China-led foreign aid, but is very different from the "One Belt and One Road" initiative.

(3) The "One Belt and One Road" initiative is called the "China's Marshall Plan"

On the basis of the above two concepts, with the introduction of the "One Belt and One Road" initiative, especially during the APEC Beijing summit, China announced the establishment of the Asian infrastructure investment bank and the silk road fund successively, and many Chinese and foreign media quickly described the "One Belt and One Road" initiative as "China's Marshall plan". It was also pointed out that "the so-called 'China's Marshall Plan' refers to China's foreign investment and development plans for Asian, central Asia and other regions based on the 'One Belt and One Road' plan." Among them, the interrelated strategic arrangements of the Bricks bank, the Asian infrastructure investment bank and the silk road fund have been summarized as the key arrangements of the "China's Marshall plan".

Many commentators think the "One Belt and One Road" initiative as similar to the US "Marshall Plan" more than 60 years ago. Many review articles have mentioned, "new Marshall Plan" has three functions. First, reduce foreign exchange reserves through foreign investment. Second, reduce overcapacity in infrastructure. Third, promote the internationalization of RMB.

In addition to the analogy between the "One Belt and One Road" initiative and the "Marshall plan" from an economic perspective, there is also a geopolitical perspective to judge the two. "It is no accident that China's 'One Belt And One Road' plan is comparable to the Marshall plan. Both are rising forces trying to use economic means to achieve foreign policy goals, including, of course, the basic goal of supporting domestic economic development. The Marshall plan helped make the United States "a true superpower country", and Beijing is counting on the "One Belt and One Road" initiative to achieve the same goal. The director of the European international political and economic centre, Lee mushing pointed out, it is a mistake to look at "One Belt and One Road" only from an economic perspective. "One Belt and One Road" is a geopolitical reorientation, and is a China's Marshall Plan. Supporting the construction of infrastructure in surrounding countries will make Beijing become Asia's most important influence of power. 


\section{3. "The One Belt and One Road" Initiative Is Not "China's Marshall Plan"}

In some ways, though, the analogy between "One Belt and One Road" initiative and China's Marshall Plan is not entirely unreasonable. In particular, the "One Belt and One Road" initiative has a positive effect on the economic pull of China itself and the countries along the routes and the development of regional integration. It is fully possible for that Marshall plan to play a similar role in the post-war European economic recovery and in the European integration process. However, due to the totally different historical background, China and the United States have different positioning and goals for their respective initiatives (or plans). There are essential differences between the "One Belt and One Road" initiative and the Marshall plan in form, content and implementation way.

(1) The fundamental attribute of the "One Belt and One Road" initiative is common development

The "One Belt and One Road" initiative is, first and foremost, a strategy of common development characterized by openness and inclusiveness. Different from the bipolar background of the Marshall plan, today's world is increasingly interdependent. The long-term and sustainable development of one country is inseparable from the development of other countries. Only through common development can countries achieve long-term development. Based on this, the "One Belt and One Road" initiative first emphasizes promoting the spirit of peace, friendship, openness and inclusiveness of the ancient Silk Road, avoiding the design of an exclusive system, targeting no third parties and not operating a sphere of influence. Any country along the route that is willing to cooperate can participate. It is a fully open joint initiative. At present, more than 50 countries along the routes have expressed their support for the "One Belt and One Road" initiative, including big countries, small countries, developed countries and a large number of developing countries. This fully embodies the openness and inclusiveness of the initiative. In addition, the support fund initiated by China, whether it is the Asian infrastructure investment bank or the Silk Road fund, will welcome the participation and cooperation of other countries under the principle of openness.

As a developing country, China has gained a deeper understanding of many factors restricting the development of developing countries through its own development and practice of foreign cooperation. More importantly, China has explored a common development model with Chinese characteristics in its long-term cooperation with developing countries. The main manifestation is to reject the aid model with conditions attached by western countries and adopt mutual beneficial cooperation based on equal consultation instead. By making comprehensive use of aid, investment and trade, it can solve the infrastructure bottleneck that restricts the development of a country, give full play to the inherent advantages of developing countries and achieve win-win development The "five links" goals of policy communication, road connectivity, unimpeded trade, currency circulation and common hearts and minds proposed by the "One Belt and One Road" initiative are the inheritance and innovation of the above common development model under the new situation.

Countries along the "One Belt and One Road" are mostly developing countries. They are in the initial or accelerated stage of industrialization and urbanization, and are faced with the difficulties of shortage in construction funds and lack of technical experience. Some of these countries are rich in energy resources, some have large markets and some need to build infrastructure. This is very different and complementary to China. While giving full play to its own advantages, China can develop with other countries to complement each other's advantages. Therefore, the "One Belt and One Road" initiative is a strategic concept of long-term common development between China and countries along the routes. It provide a development platform with great inclusiveness, which aims to achieve that goal of mutual exchange, win-win cooperation and common development by interconnection to play the comparative advantage of regional economy. By contrast, the Marshall plan is American post-war aid plan to Western Europe. Despite its multiple objectives, it is, first and foremost, a political and security strategy with clear exclusiveness.

The battle between the United States and the Soviet Union over a political vacuum in post-war Europe is the background for the Marshall plan "Marshall himself later said that the final decision to provide immediate aid to Europe was made after the failure of a meeting of four foreign ministers in Moscow in 1947." "Marshall believed that the Soviet government had stalled and would not agree to any feasible plan that might ease the tension and crisis in Europe, but would take all possible measures 
to worsen the situation in Europe." Thus it can be seen that the Marshall plan excluded the Soviet Union from the very beginning, which has obvious characteristics of exclusiveness and power seeking. Accordingly, the Marshall plan is considered a turning point in the formation of the two camps and the origin of the cold war.

After the war, western European countries suffered from poor economy, left-leaning politics and rising socialist ideological influence. The Marshall plan aims to achieve double control over the European economy and politics through conditional aid to Europe, curb the influence of Soviet socialism, and consolidate the established hegemony of the United States with strong ideology Article 1 of the 1948 foreign aid act states that "the restoration or maintenance of the principles of freedom, free institutions and genuine independence of European countries is largely based on good economic conditions". This shows that policy makers are not only concerned about economic aid, but also about ideological political goals. As Clark Clifford, a special adviser to the US president, put it, "we are not worried about the markets but about preventing the Soviet Union from expanding its control. The Second World War left a huge political vacuum in the free world, and the Soviet Union was determined to fill it, which was the basis of the Marshall plan."

Thus, the Marshall plan is a political and security strategy based on ideology. The planers of Marshall Plan feared that the Soviet Union would use the European crisis to further expand its influence and threaten American security. Only the United States has enough economic power to revitalize Europe and offer hope to Asia's non-communist countries. Without aid, the growing chaos will threaten the free world and American interests severely. In this case, George Kennan says, "the economic loss of order makes European society vulnerable to the use of totalitarian politics. The Marshall plan is an effective tool for containment strategy." Since the outbreak of the Korean War, military security has replaced economic self-reliance as the main objective of US policy in Western Europe. To underscore the importance of economic power to the military security infrastructure, $\$ 1.5$ billion of recovery program aid was positioned as "defence support." Finally, on October 10, 1951, the mutual security act was passed. The common security agency replaced the economic cooperation agency, further demonstrating the political and security nature of the Marshall plan.

(2) The "One Belt and One Road" initiative follows the principle of equality and mutual benefit

Mutual respect and non-interference in each other's internal affairs are the fundamental principles of Chinese diplomacy and will certainly be reflected in the cooperation of the "One Belt and One Road" initiative. For a long time, China has cooperated with other developing countries, fully respecting the autonomy of relevant countries and attaching no conditions to cooperation. The "One Belt and One Road" initiative will continue to adhere to the above principles and emphasize "joint consultation, joint development and joint sharing". Relevant countries participate on a voluntary and equal basis, make their own decisions based on their own interests, and jointly build a community of shared development, a community of shared interests and a community of shared responsibilities.

During the "dialogue on connectivity partnership" held during the APEC meeting, President Xi jinping reiterated that "we should build connectivity and achieve Asia's interconnected development", "we should respect the sovereignty and territorial integrity of all countries, accommodate the comfort level of all parties, not impose on others, and not interfere in other countries' internal affairs". At the BBS conference on China-Arab cooperation, Arab states said that they are full of expectations for the silk road economic belt because China has adopted an equal and open attitude in the process of advancing the initiative, and has not pursued selfish interests, not engaged in sphere of influence, not interfered in other countries' internal affairs, not imposed on others, and not competed with other major powers and existing mechanisms.

The basic concept of the implementation of the "One Belt and One Road" initiative is "strategic alignment", which is in line with development strategies of partner countries and regions. It fundamentally embodies the principle of autonomy and equality in cooperation with partner countries. Taking "strategic alignment" as the basic concept is not only the requirement of the principle of equality and mutual benefit, but also the successful experience summary of cooperation between China and the international community. From the consultation with partners in the initial stage of the initiative, to the progress of the current early projects, whether it is the connection with Kazakhstan's 
"bright road" plan or the "industrial park plan" with Indian transport infrastructure construction plan, it fully reflects the concept of "strategic alignment". In contrast, the Marshall plan attached many unequal conditions to the aid and obtained powerful means to intervene the internal economic policies of western European countries.

"The key channel through which the Marshall Plan works is through the conditions attached to it, to make the United States have a significant impact on the economic policies of the recipient countries." The Marshall plan first established the conditions for joint assistance, that is, the nonavailability of aid to individual countries, in order to bind western European countries together under the influence of the United States. In addition, the United States has put forward specific conditions of assistance. Recipient countries have signed bilateral treaties with the United States, pledging to balance budgets, restore financial stability, stabilize exchange rates and strengthen cooperation. In addition to providing "carrots" and "sticks", the Marshall plan is similar in many ways to the IMF's macroeconomic adjustment programme. Aid, for example, is not freely available, but is used to buy foreign goods with the consent of the United States government. Recipient countries are also required to set up domestic cash accounts, namely counterpart funds that will be used with approval from the relevant Marshall Plan authorities.

In fact, the United States has gained control over double aid resources by sharing the right to dispose of the "counterpart funds". Therefore, the United States deprived recipient countries of the right to independently formulate economic policies, and realized the integration of Europe into the leading liberal economic policy order to maintain the economic hegemony of the United States. Finally, in order to divert excess capital and productivity from the US, most of its aid to Europe is required to buy US goods. By the end of June 1950, US assistance to Europe amounted to $\$ 9.46$ billion, of which $\$ 8.8$ billion was required through the purchase of goods authorization. According to a French pollster poll in September 1947, 18 percent of respondents believed the Marshall plan was sincere in helping Europe recover, 17 percent said the United States was meddling in European affairs, and 47 percent said the United States needed external markets to avoid an economic crisis.

(3) The "One Belt and One Road" initiative is based on pragmatic cooperation

"One Belt and One Road" is a concept and initiative of win-win cooperation, not an entity or mechanism. In line with the principle of pragmatism and efficiency, the initiative will make full use of existing cooperation mechanisms, innovate cooperation forms and promote common development flexibly according to different development priorities and conditions of countries along the routes. The "One Belt and One Road" initiative does not seek to achieve the leading right through the new system design, and follows the pragmatic cooperation principle based on local conditions and projectorientation. Relying on existing cooperation mechanisms also shows a pragmatic attitude of respecting the logic of regional development. More than 60 countries along the "One Belt and One Road" are widely distributed in Eurasia and west Asia and North Africa. There are significant differences in the economic, political and security environment and in the degree of integration of different regions, making it difficult to cooperate effectively in a unified multilateral framework. In September 2013, when President Xi jinping first proposed the construction of the "silk road economic belt" in Kazakhstan, he stressed that relevant cooperation should be carried out from point to area, and from line to piece and gradually form the concept of big regional cooperation. In November 2014, when the central leading group of finance and economics studied the "One Belt and One Road" plan, President Xi jinping once again stressed that the construction of "One Belt and One Road" should be carried out from point to line and from line to area. The "point" here mainly refers to project cooperation in a bilateral framework.

At present, the "One Belt and One Road "initiative has been launched in many partnerships and regional cooperation frameworks, and has made many early progress. For example, the joint inscription with central Asian countries, the construction of east-west railway projects in Turkey and the all-round capacity cooperation with central Asian countries all show the characteristics and vitality of the pragmatic cooperation of the "One Belt and One Road" initiative.

Compared with the pragmatic cooperation of the "One Belt and One Road" initiative, the Marshall plan aims to seek the dominance of European affairs and the hegemony of the US through institutional 
arrangements and rules formulation. "The importance of aid is not its size, but its impact on European economic, fiscal and monetary policy." To implement the Marshall plan, the United States first pushed for the establishment of "the organization for economic cooperation in Europe". Although the organization was founded on the principle of "self-help and self-rescue", the position of the United States as an observer and the advantage of a donor made it an important institutional tool for the United States to exert influence on the internal affairs of Europe.

During the implementation of the Marshall plan, the organization mainly played the role of analysing the common economic difficulties and problems of recipient countries, coordinating policies of recipient countries, eliminating trade barriers within Europe, forming a multilateral payment system and establishing a "European payment union". It is through these institutional functions that the United States broke the situation that the internal currencies of Western Europe could not be freely convertible, made the dollar the settlement currency in European countries, established the hegemony of the dollar, changed the pattern of rigid trade barriers among European countries, and established the new post-war economic order dominated by the United States in Europe.

\section{The Implementation of the "One Belt and One Road" Initiative Faces Greater Challenges}

The implementation of the "One Belt and One Road" initiative will face greater challenges than the Marshall plan. Whether it is the diversity of the countries involved, the breadth of the areas of cooperation, or the complexity of the international environment, the challenges faced by the implementation of the "One Belt and One Road" initiative cannot be compared to the Marshall plan.

In terms of partners, the intended targets of Marshall Plan are western European countries which share the same values with the United States. In view of that common perception of the US propagated communist threat, coupled with common economic difficulties, countries are easily agree upon the necessity for United States assistance. As a result, the Marshall plan received the most positive response from Britain and France when it was first proposed, and western European countries soon established the organization for economic cooperation in Europe and agreed on the principles of cooperation. By contrast, countries along the "One Belt and One Road" are not only diverse and heterogeneous, but also have different understandings of China. There are conflicts between them, some of which are even at the core of the game of great powers, increasing the economic, political and security risks of pragmatic cooperation. How to cope with diversified development demands, complex regional security situation and rising geopolitical risks will be the main challenge faced by the "One Belt and One Road" initiative.

In terms of areas and scope of cooperation, the Marshall plan is a US-led aid program with relatively single areas of cooperation. In terms of actual implementation, the Marshall plan provides assistance mainly through three stages. The first is to provide a large number of food, raw materials and substitutes to alleviate the shortage of materials. The main features of the second stage are new investment plans, including assistance for modern industry and energy equipment, especially equipment for expanding domestic investment. The third stage is to deal directly with the production efficiency of western European countries. The "One Belt and One Road" initiative is a comprehensive cooperative project covering a wide range of areas, including trade, investment, finance, transportation and humanities. And it hopes to achieve the concept of big regional cooperation, from point to area, from line to piece. This is bound to involve more bilateral coordination, multilateral docking and communication and integration problems in a series of rules and standards.

In view of the complexity of the international environment, the implementation of the Marshall plan is in a bipolar pattern, and the US assistance to Western Europe is not interfered by many factors outside the region. The "One Belt and One Road" initiative faces a more complex international environment. At present, China's comprehensive national strength and international status are rising rapidly. But because the political system, ideology and development road are different from the west, and the latter is suspicious of China's development direction. Despite China's repeated statements that 
it does not seek hegemony, its growing influence has raised western concerns and is seen as a potential major force challenging the existing international order. The establishment of the Bricks bank, the Asian infrastructure investment bank and the Silk Road fund is seen as an effort by China to reconstruct international order.

\section{Objective and Rational View of the Similarities and Differences Between the Two}

The analogy between the "One Belt and One Road" initiative and the Marshall plan needs to be treated rationally and differently, and should not be regarded as a smear against the former. First, from the logic of economic development, they do have common features. This is why Chinese scholars advocate the "China's Marshall Plan". The large-scale investment required to achieve the goal of interconnection will actually drive the economic development of China and its partners and play an objective role in promoting regional integration, similar to the role of the Marshall plan in revitalizing the European economy and promoting European integration. Second, while the fundamental nature of the Marshall plan is political and security strategy, its role is also controversial. But overall, the west's assessment of the Marshall plan is positive. Third, although the fundamental nature of the "One Belt and One Road" initiative is common development, the goal of achieving common development has never been isolated and will be conducive to realizing the goal of maintaining peace in Chinese foreign policy.

Despite the fundamental differences, the implementation of the Marshall plan can provide both positive and negative experiences and lessons for the "One Belt and One Road" initiative, especially, in the aspect of how to enhance the flexibility of cooperation and enhance internal and external coordination and coordinate capacity. During the implementation of the Marshall plan, the United States not only required Europe to set up a coordinating body, but also set up the Economic Cooperation Administration (ECA), which is independent from the state council and directly responsible to the President, to strengthen internal and external coordination. "The role of the ECA is unprecedented in the external relationship during the peacetime in the United States. ECA's communication with recipient countries is much broader than that between traditional embassies and foreign liaison agencies. It is constantly communicating within the United States with various government departments, including the treasury department, the department of economics, the department of agriculture and a wide range of private interest groups."

Currently, the "One Belt and One Road" initiative is still in its initial stage of implementation. In order to avoid misunderstanding, it is necessary to take targeted communication measures for the analogy of Marshall Plan. In view of the vast number of developing countries along the routes, in addition to highlighting the above differences and removing their concerns, it should be noted that the "One Belt and One Road" initiative is not Marshall Plan type assistance, but win-win cooperation under the framework of south-south cooperation. China is an advocate of cooperation, not a leader. For western countries, we should focus on responding to their concerns about "China re-establishing order" and highlight the "One Belt and One Road" initiative for economic cooperation and common development, without avoiding the spilled political and diplomatic effects of cooperation.

The "One Belt and One Road" initiative has received positive comments from governments of countries along the routes, but it is not well recognized by scholars and the public. Therefore, on the one hand, it is necessary to increase the outside world's understanding of the initiative through various international seminars, Sino-foreign joint subject research and other forms. On the other hand, an outline document could be issued at the national level to explain the main ideas and roadmap of the initiative. More importantly, we need to accelerate concrete cooperation under the framework and use the results of practical cooperation to demonstrate to the outside world the fundamental nature of common development. 


\section{References}

[1]. Lin yifu, "use 'new Marshall Plan' to lead the global recovery", Ten cent, October 22, 2012, http: / / Edu. Qq. com / a /20121022 /000102_1. Ham.

[2]. "China's Marshall Plan proposed by CPPCC member Xu shanda", Economic information daily, August 6, 2009.

[3]. "The concept of China's Marshall Plan can serve several purposes", Shanghai securities news, November 7, 2014.

[4]. Lai aiming: "The press is firing the new Marshall plan," The securities times, November 7, 2014.

[5]. Shannon Tizzy, “The New Silk road: China’s Marshall Plan? “The Diplomat, November 6, 2014.

[6]. Michele Pena, "China's Marshall Plan: All Silk roads lead to Beijing? "World Politics review, December 9, 2014.

[7]. Ladislav Tajo sky, Mate Karce, "The Marshall Plan and Its relation to the Beginning of the Cold War, Prague Papers on the History of International relations, Prague: Institute of World History, 2009, pp. 465- 478.

[8]. Harry Bayard Price, The Marshall Plan and Its Meaning: An Independent and Unbiased Appraisal of the Entire record, Cornell University Press, Ithaca, New York, 1955, p. 4.

[9]. The 80th Congress, 2nd Session, “Foreign Assistance Act of 1948,"Article 1, April 3, 1948.

[10]. Jerry N. Hess, “Oral History Interview with Clark M. Clifford, March 23, 1971, http: / / www. Truman library. org / moralist / cliford1. Ham. (Online time: December 29, 2014).

[11]. Diane B. Kunz, “The Marshall Plan reconsidered, ”Foreign Affairs, Vol. 76, No. 3, p. 165.

[12]. "Xi jinping hosted a dialogue on strengthening the connectivity partnership and delivered an important speech ", Ministry of foreign affairs website, November 8, 2014, http: / /www. Marc. Gov. Can / moa- chin / zillion- 611306 / at- 611380 / dent- 611382 / idyll- 667839 / six- 667918 / t1208701. Shtum.

[13]. Liu jianchao, "Practical cooperation to promote the construction of the Silk Road economic belt", Ministry of foreign affairs website, July 2, 2014, http: / /www. Marc. Gov. Can / moa- chin / zillion- 611306 / at- 611380 / dent- 611382 / idyll- 667839 / wjbxw- 667920 / t1170782. Shtum.

[14]. "Mr. Duisenberg Assesses What We have Learned from the Marshall Plan" BIS Review, 54 /1997, http: / / www, bus. Org / review / r970602c. Pdf. 